\title{
The orotate transporter encoded by oro $P$ from Lactococcus lactis is required for orotate utilization and has utility as a food-grade selectable marker
}

\author{
Correspondence \\ Jan Martinussen \\ jma@biocentrum.dtu.dk
}

Received 12 January 2007

Revised 14 June 2007

Accepted 13 July 2007

\author{
Els Defoor, Maj-Britt Kryger and Jan Martinussen
} Center for Systems Microbiology, BioCentrum-DTU, Building 301, Technical University of Denmark,
DK-2800 Kgs. Lyngby, Denmark

\begin{abstract}
A new lactococcal plasmid, pDBORO, was isolated from the Lactococcus lactis subsp. lactis biovar diacetylactis strain DB0410. This plasmid is responsible for the sensitivity of DB0410 to the toxic pyrimidine analogue 5-fluoroorotate. The complete nucleotide sequence has been determined and amounts to $16404 \mathrm{bp}$. Of 15 ORFs encountered, three were found to be insertion sequence (IS) elements, identified as two IS946 and one IS982. Two ORFs are incomplete due to the insertion of an IS element in their C-terminal region. Homologues for four ORFs were found in the IL1403 sequence: the $\operatorname{cop} B$ gene, coding for a copperpotassium-transporting ATPase $\mathrm{B}$, and the $y s b A, y s b B$ and $y s b C$ genes. The structural organization of the $\mathrm{pDBORO}$ replication region is highly similar to other theta-replicating plasmids in both the cis- $(r e p A)$ and trans-acting (repB and orf $X)$ sequences. By plasmid deletion analysis and molecular cloning, a single locus on pDBORO was found to confer sensitivity to 5 -fluoroorotate. It was identified as $y s b C$, but renamed oro $P$ in order to reflect its function. The oroP gene was found to be essential for the utilization of orotate as the sole pyrimidine source in a strain deficient in pyrimidine de novo synthesis. The amino acid sequence encoded by the ORF showed the characteristic features of a membrane protein. Therefore, oro $P$ most probably encodes an orotate transporter. Surprisingly, homologues of oroP could be identified in the genomes of both L. lactis MG1363 and L. lactis IL1403 despite the fact that these strains were unable to significantly utilize orotate. Cloning of oroP in Escherichia coli and Bacillus subtilis showed that the orotate transport phenotype could be transformed to both organisms. The findings presented indicate that oro $P$ can be used as a powerful, food-grade selection/ counterselection marker in many different organisms.
\end{abstract}

\section{INTRODUCTION}

Lactococcus lactis strains are widely used in the dairy industry as starter cultures in cheese fermentation. All $L$. lactis species isolated so far from starter cultures contain a number of different plasmids. These plasmids are thought to have been acquired during adaptation, and many plasmid-encoded functions have been related to or are essential for growth in milk. Examples are genes involved in lactose transport and metabolism (Efstathiou \& McKay, 1976), genes encoding proteinases necessary for casein degradation (Efstathiou \& McKay, 1976; McKay et al., 1976) and di- and oligopeptide transport genes (Yu et al., 1995a, 1996).

Pyrimidine metabolism has been extensively studied in $L$. lactis in our laboratory (Andersen et al., 1996; Jorgensen

The GenBank/EMBL/DDBJ accession number for the oro $P$ region is DQ089807; the accession number for the total pDBORO sequence is EF210104. et al., 2003, 2004; Kilstrup \& Martinussen, 1998; Martinussen et al., 1994, 1995, 2001, 2003; Martinussen \& Hammer, 1994, 1995, 1998; Wadskov-Hansen et al., 2000, 2001), and a review of nucleotide metabolism in lactic acid bacteria has recently been published (Kilstrup et al., 2005). In L. lactis, pyrimidines can be synthesized de novo or can be salvaged from the growth medium (Martinussen et al., 1994). The pyrimidine de novo synthesis pathway consists of six steps leading to the formation of UMP and seems to be universal among all organisms. L. lactis is also able to metabolize various pyrimidine nucleosides and nucleobases, but not cytosine, due to the lack of cytosine deaminase (Martinussen et al., 1994).

Orotate is an intermediate in the pyrimidine biosynthetic pathway. It is formed in the fourth step, in which dihydroorotate is converted into orotate by dihydroorotate dehydrogenase, encoded by the pyrD gene. A surprising discovery in L. lactis is the presence of two genes, pyrDa and $p y r D b$, both coding for a functional dihydroorotate dehydrogenase (Andersen et al., 1994, 1996) (Fig. 1). Later 


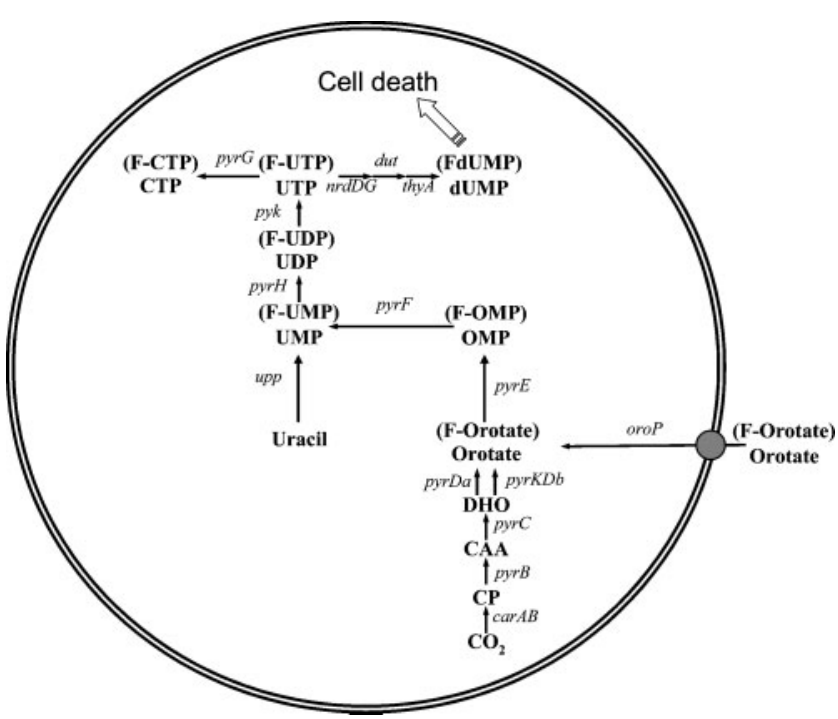

Fig. 1. Pyrimidine metabolism in L. lactis. The metabolism of both the normal intermediates and the 5-fluoro-substitituted pyrimidines (shown in parentheses) is mediated by the same enzymes. Note that formation of 5-fluorodeoxyuridine monophosphate (FdUMP) leads to cell death. The individual enzymes are represented by their gene symbols. The following abbreviations are used: $\mathrm{CP}$, carbamoyl phosphate; CAA, carbamoyl aspartate; DHO, dihydroorotate; OMP, orotate monophosphate. The enzymic reactions are represented by the corresponding genes: car $A B$, carbamoyl phosphate synthase; dut, dUTPase; nrdDG, anaerobic ribonucleotide triphosphate reductase; $p y k$, pyruvate kinase; $p y r B$, aspartate transcarbamoylase; pyrC, dihydroorotase; pyrDa, dihydroorotate dehydrogenase $A ;$ pyrKDb, dihydroorotate dehydrogenase $B$; pyrE, orotate phosphoribosyltransferase; pyrF, OMP decarboxylase; pyrG, CTP synthase; $p y r H$, UMP kinase; thy $A$, thymidylate synthase; upp, uracil phosphoribosyltransferase.

the same was reported in Enterococcus faecalis (Marcinkeviciene et al., 1999, 2000). Searching for homology revealed that Streptococcus spp. also harbour two pyrD genes, suggesting that this might be a characteristic of these closely related organisms. Milk contains a high concentration of orotate, which disappears during fermentation in the presence of lactic acid bacteria, including L. lactis cultures (Kneifel et al., 1992; Saidi \& Warthesen, 1989). This finding suggests that at least some lactic acid bacteria can metabolize orotate. Growth of Lactobacillus bulgaricus is stimulated by orotate but no transporter has been identified yet (Suzuki et al., 1986). Pyrimidine-requiring mutants of both Escherichia coli and Salmonella typhimurium can utilize orotate as their sole pyrimidine source after transport into the cell mediated by the $\mathrm{C}_{4}$-dicarboxylic transport protein DctA (Baker et al., 1996). DctA also mediates the transport of orotate in Sinorhizobium meliloti (Yurgel \& Kahn, 2005). However, no homology to the deduced amino acid sequence of $d c t A$ was found in the databases of published lactic acid bacteria genomes.
Pyrimidine analogues in which the hydrogen at the $5^{\prime}$ position has been substituted with a fluoride group have been used to analyse pyrimidine metabolism in many different organisms, including L. lactis (Martinussen et al., 1994; Martinussen \& Hammer, 1995). 5-Fluoropyrimidines are only toxic to the cell after being converted by the enzymes of pyrimidine metabolism. The most toxic metabolite is 5-fluorodeoxyuridine monophosphate (FdUMP, Fig. 1), which prevents formation of dTMP by thymidylate synthase since it covalently binds to the enzyme. Hence, 5-fluoroorotate is transported and metabolized by the same enzymes that metabolize orotate.

Our research focuses on the elucidation of orotate metabolism in L. lactis. This article reports the screening of $L$. lactis strains for their ability to utilize orotate, and the cloning and characterization of a gene, oroP, encoding an orotate transporter. In strains able to utilize orotate, the oroP gene was found on plasmids. Interestingly, homologues of oroP could be identified on the genomes of the $L$. lactis strains MG1363 and IL1403 despite the fact that these strains were unable to utilize orotate. oroP was found to be functional also in Escherichia coli and Bacillus subtilis. The results show that oroP can be exploited as an efficient selection/counterselection marker.

Plasmids found in lactococci replicate either via the sigma or rolling-circle replication mode, in which single-stranded DNA is produced as a replication intermediate (Hayes et al., 1990), or via the theta mode. Several theta-replicating plasmids can coexist in a single cell, explaining the many plasmids of different sizes found in lactococci. These plasmids are extremely stable, both structurally and segregationally, and exhibit a narrow host range (Frere et al., 1993; Hayes et al., 1991; Seegers et al., 1994).

\section{METHODS}

Growth conditions. Lactococcal cultures were grown, unless otherwise stated, at $30{ }^{\circ} \mathrm{C}$ either in M17 broth (Terzaghi \& Sandine, 1975) or in defined SA medium (Jensen \& Hammer, 1993) supplemented with $1 \%$ glucose (GSA). Strains DB0410, NCDO712, CHCC336, FHCY-1 and 3107 were propagated in the presence of lactose at $1 \%$ (LSA) instead of glucose. E. coli strains were grown at $37{ }^{\circ} \mathrm{C}$ in Luria-Bertani (LB) broth or in minimal ABT glucose medium (Clark \& Maaloe, 1967). B. subtilis strains were grown at $37{ }^{\circ} \mathrm{C}$ in LB broth or in minimal MM medium (Saxild \& Nygaard, 1987). Agar plates were made by adding agar $\left(15 \mathrm{~g} \mathrm{l}^{-1}\right)$ to the broth medium. Supplements were added to the different media at the following concentrations unless otherwise indicated: orotate at $20 \mu \mathrm{g} \mathrm{ml} l^{-1}$, uracil at $20 \mu \mathrm{g} \mathrm{ml}^{-1}, 5$-fluoroorotate at $20 \mu \mathrm{g} \mathrm{m}^{-1}$, erythromycin at $5 \mu \mathrm{g} \mathrm{m}{ }^{-1}$, chloramphenicol at $5 \mu \mathrm{g} \mathrm{ml} l^{-1}$ for lactococci and $20 \mu \mathrm{g} \mathrm{ml}^{-1}$ for E. coli, ampicillin at $100 \mu \mathrm{g} \mathrm{ml}{ }^{-1}$. Transformation of L. lactis was performed by electroporation (Holo \& Nes, 1995). For selection of transformants of ED79.1175 by the ability to grow on orotate as sole pyrimidine source, cells were spread on agar plates containing SA medium, $1 \%$ glucose, $250 \mathrm{mM}$ sucrose, $2.5 \mu \mathrm{M} \mathrm{CaCl}_{2}, 2.5 \mu \mathrm{M} \mathrm{MgCl}$ and $100 \mu \mathrm{g}$ orotate $\mathrm{ml}^{-1}$. E. coli cells were transformed using the calcium chloride procedure (Mandel \& Higa, 1992). Transformation of B. subtilis cells was carried out as previously described (Boylan et al., 1972): competent B. subtilis cells 
were obtained by adding $3 \mathrm{ml}$ of an overnight culture (not lysed) grown in GM1 medium to $10 \mathrm{ml}$ fresh GM1 medium and incubation for $4.5 \mathrm{~h}$ at $37^{\circ} \mathrm{C}$. The bacterial culture was subsequently diluted $1 / 10$ in GM2 medium and incubated for $1 \mathrm{~h}$ at $37{ }^{\circ} \mathrm{C}$. For 168MIU6 ( $\operatorname{trpC} 2$ pyrB) cells, $20 \mu \mathrm{g}$ uracil $\mathrm{ml}^{-1}$ was added to the GM1 and GM2 media. For the transformation, $1 \mathrm{ml}$ of the competent culture was mixed with 10 or $30 \mu$ of the linearized plasmid solution $\left(100 n g \mu l^{-1}\right)$ and the mixture was incubated for $35 \mathrm{~min}$ at $37^{\circ} \mathrm{C}$. Cells were centrifuged for $4 \mathrm{~min}$ and the cell pellet was resuspended in $200 \mu \mathrm{l} 0.9 \%$ $\mathrm{NaCl}$ solution and plated on selective LB agar plates containing $5 \mu \mathrm{g}$ neomycin $\mathrm{ml}^{-1}$. The agar plates were incubated overnight at $37^{\circ} \mathrm{C}$.

Molecular cloning techniques. Standard molecular cloning techniques were used according to Sambrook et al. (1989). Chromosomal DNA from lactococci was prepared as previously described (Johansen \& Kibenich, 1992). Chromosomal DNA from $B$. subtilis was prepared according to Saxild \& Nygaard (1987). Plasmid DNA was obtained by purification on Qiagen anion-exchange columns using the protocols supplied by the manufacturer. Plasmid DNA from lactococci was purified using the following modifications. Cells were resuspended in P1 buffer containing $20 \mathrm{mg}^{\text {lysozyme } \mathrm{ml}^{-1}}$ followed by $20 \mathrm{~min}$ incubation at $37^{\circ} \mathrm{C}$. Purification on the Qiagen anion-exchange column was omitted. Isolation of plasmids from DB0410 and 901-1 was carried out by the adapted Qiagen protocol for the isolation of BAC and PAC clones, and of the pDBORO plasmid for sequencing purposes by the Qiagen very-low-copy plasmid purification protocol.

PCR amplification of DNA. Amplification of DNA was performed on 50 ng DNA in a final volume of $50 \mu \mathrm{l}$ containing $200 \mu \mathrm{M}$ of each deoxyribonucleoside triphosphate, $200 \mathrm{nM}$ of each oligonucleotide, and Taq polymerase. AmpliTaq DNA polymerase (2.5 U) was used in the verification experiments. For cloning purposes either Pfu DNA polymerase, TaqPlus Precision polymerase mixture or Elongase (Invitrogen) was used according the manufacturer's recommendations. Amplification was performed with $25-30$ cycles of $95{ }^{\circ} \mathrm{C} 50 \mathrm{~s}$, $50{ }^{\circ} \mathrm{C} 50 \mathrm{~s}$ and $72{ }^{\circ} \mathrm{C} 1-5 \mathrm{~min}$.

Nucleotide sequences. Nucleotide sequences were determined by MWG-Biotech. The sequence of the oroP region has been assigned the GenBank accession number DQ089807; the total pDBORO sequence can be accessed by the GenBank number EF210104.

Bacterial strains and plasmids. The bacterial strains, plasmids and primers used in this work are shown in Tables 1 and 2. All plasmids were analysed by restriction enzyme analysis and sequencing; all recombinant strains were verified by PCR.

The MG1363 mutant ED79.1175 harbours deletions of both pyrDa and $p y r D b$, resulting in a pyrimidine requirement which can be satisfied by uracil. This mutant was constructed in two steps. In the first step, the MG1363 $\Delta$ pyrDa mutant ED58.82 was made. To achieve this, plasmids pRL101, pED102 and pED202 were constructed. pRL101 containing $\triangle p y r D a$ was constructed in the following way. A PCR fragment was amplified with primers pyrDaBamHI and pyrDaNcoI using pIP61 (Andersen et al., 1994) as template. Both pIP61 and the PCR fragment were digested with BamHI and NcoI, ligated together and transformed into E. coli XL1-Blue at $37^{\circ} \mathrm{C}$ with selection for $100 \mu \mathrm{g}$ ampicillin $\mathrm{ml}^{-1}$, resulting in pRL101. Plasmid pED102 was obtained in the following way. Using pRL101 as template and the primers pyrDaBamHI and pyrDaHindIII the $\Delta p y r D a$ allele was amplified by PCR. The fragment was subcloned into the vector pCR2.1-TOPO using the TOPO-TA cloning system. Plasmid pED202 was constructed by ligating pED102 and pGhost $^{+} 4$ (Maguin et al., 1992) together at the $X b a \mathrm{I}$ site, which is unique in both plasmids. After transformation into E. coli XL1-Blue, the fusion plasmid was obtained by selection at $37{ }^{\circ} \mathrm{C}$ on LB agar plates containing both $100 \mu \mathrm{g}$ ampicillin $\mathrm{ml}^{-1}$ and $150 \mu \mathrm{g}$ erythromycin $\mathrm{ml}^{-1}$. Plasmid pED202 was transformed into L. lactis MG1363, selecting for erythromycin resistance at $28{ }^{\circ} \mathrm{C}$. Using the method originally developed by Biswas et al. (1993) and improved by Martinussen \& Hammer (1994), the $\triangle p y r D a$ allele was exchanged with the wild-type, resulting in the mutant ED58.82.

In the second step, the pyrD double mutant ED79.1175 was created by deletion of a $780 \mathrm{bp}$ internal fragment in the $p y r D b$ gene. This was carried out in the following way. Two PCR fragments were amplified in separate reactions with MG1363 chromosomal DNA as template using pyrDbIF and pyrDbIR in one reaction and pyrDbIIF and pyrDbIIR in the other. Since the primers pyrDbIR and pyrDbIIF are partially complementary, the two PCR products could be used as templates in a new PCR reaction with primers pyrDbIF and pyrDbIIR. The resulting PCR fragment containing the pyrDb deletion was cloned into the vector pCR2.1-TOPO, yielding pED105. Plasmid pED204 was made by ligating pED105 and pGhost ${ }^{+} 4$ together at the $X b a I$ site and transforming into E. coli XL1-Blue as described above for $\mathrm{pED} 202$. The wild-type allele $p y r D b$ was exchanged with $\triangle p y r D b$ as described above for ED58.82 ( $\triangle p y r D a)$, thus obtaining the pyrD double mutant ED79.1175.

A $3.8 \mathrm{~kb}$ DNA fragment was amplified using pDBORO plasmid DNA and the primer set DBORO2/DBORO8. The PCR fragments were cloned into the vector PCR2.1-TOPO and recombinant plasmids were selected at $37{ }^{\circ} \mathrm{C}$ on LB agar plates containing $100 \mu \mathrm{g}$ ampicillin $\mathrm{ml}^{-1}$. The recombinant plasmid pED112 harboured oroP and $y s b B A$.

An EcoRI fragment from pED112 was ligated into the unique EcoRI site of pCI3440 (Hayes et al., 1990) and amplified in E. coli XL1-Blue at $37{ }^{\circ} \mathrm{C}$ with selection for resistance to $20 \mu \mathrm{g}$ chloramphenicol ml $\mathrm{m}^{-1}$. The resulting plasmid was called pED210.

With pDBORO as template and primers DBORO18 and CS105, a PCR product was obtained and cloned into pCR2.1-TOPO. The recombinant plasmid pMBK701 was obtained after transformation into L. lactis ED79.1175 and selection for growth on GSA plates supplied with orotate as sole pyrimidine source.

A DNA fragment containing the oroP gene was amplified with primer set DBORO22BamHI/DBORO23EcoRI using pDBORO plasmid DNA as template. The PCR fragment was digested with BamHI and EcoRI and ligated into the B. subtilis integrative vector pDG268 (Antoniewski et al., 1990) digested with the same restriction endonucleases. The recombinant plasmid pED301 was amplified in E. coli XL1-Blue at $37^{\circ} \mathrm{C}$ on $\mathrm{LB}$ agar plates containing $100 \mu \mathrm{g}$ ampicillin $\mathrm{ml}^{-1}$. Recombinant plasmid pED307 was constructed in the same way except that primer set DBORO22BamHI/ DBORO24EcoRI was used. Plasmid pED301 was integrated into the B. subtilis 168 amyE gene by a double cross-over recombination through the $a m y E \mathrm{~N}$-terminal and $a m y E \mathrm{C}$-terminal parts located on the pDG268 vector. The plasmid was linearized by digestion with $K p n I$ prior to transformation in order to ensure chromosomal integration by a double cross-over event. The neomycin-resistant strain ED348 was readily obtained. The control strain ED344 was obtained by transforming strain 168 with KpnI-linearized pGD268. The B. subtilis pyrimidine auxotrophic mutant 168MIU5 (trpC2 pyrB) (Potvin et al., 1975) was transformed with linearized pED307 DNA to obtain ED358 $\left[p y r B(\text { oroP- } y s b B)^{+}\right]$. As a control strain 168MIU5 was also transformed with KpnI-linearized pGD268, resulting in ED364.

Chromosomal integration by a double cross-over event was identified by the lack of $\alpha$-amylase activity of the $B$. subtilis recombinants. Integration of pED301 or pED307 DNA into the amyE gene was investigated at the chromosomal level by PCR with primer sets 268neo/DBORO20 and 268neo/DBORO04. 
Table 1. Bacterial strains and plasmids used in this work

\begin{tabular}{|c|c|c|c|}
\hline Strain & Genotype & Parental/host strain & Reference or source \\
\hline \multicolumn{4}{|l|}{ Lactococcus lactis } \\
\hline 1. NCDO712 & & & Gasson (1983) \\
\hline 2. Wg2 & & & Braun et al. (1989) \\
\hline 3. $901-1$ & & & Braun et al. (1989) \\
\hline 4. 3107 & & & Braun et al. (1989) \\
\hline 5. MG1363 & & NCDO712 & Gasson (1983) \\
\hline 6. NCDO2118 & & & $\mathrm{NCDO}^{*}$ \\
\hline 7. $\mathrm{C} 2$ & & & Huggins \& Sandine (1977) \\
\hline 8. IL1403 & & & Chopin et al. (1984) \\
\hline 9. FHCY-1 & & & $\mathrm{CHCC} \dagger$ \\
\hline 10. СНCC336 & & & $\mathrm{CHCC} \dagger$ \\
\hline 11. DB0410 & $i l v$ & & Curic et al. (1999), $\mathrm{CHCC} \dagger$ \\
\hline ED58.82 & $\Delta p y r D a$ & MG1363 & This work \\
\hline ED79.1175 & MG1363 $\Delta p y r D a \Delta p y r D b$ & MG1363 & This work \\
\hline \multicolumn{4}{|l|}{ Bacillus subtilis } \\
\hline 168 & $\operatorname{trpC2}$ & & Potvin et al. (1975) \\
\hline 168MIU5 & $\operatorname{trp} C 2$ pyrB & 168 & Potvin et al. (1975) \\
\hline ED344 & $\operatorname{trp} C 2$ amyE neo & & This work \\
\hline ED348 & $\operatorname{trp} C 2$ amyE neo $(\text { oroP-ysbB })^{+}$ & 168 & This work \\
\hline ED364 & $\operatorname{trpC2}$ pyrB amyE neo & 168 & This work \\
\hline ED358 & $\operatorname{trp} C 2$ pyrB amyE neo $\left(\right.$ oroP-ysbB-ysbA) ${ }^{+}$ & & This work \\
\hline \multicolumn{4}{|l|}{ Escherichia coli } \\
\hline XL1-Blue & $\begin{array}{l}\text { endA1 hsdR17 }\left(\mathrm{r}_{\mathrm{K} 12}^{-} \mathrm{m}_{\mathrm{K} 12}^{-}, \mathrm{r}_{\mathrm{K} 12}^{-} \mathrm{m}_{\mathrm{K} 12}^{+}\right) \text {supE44 thi-1 } \\
\text { recA1 gyrA96 relA1 lac } \mathrm{F}^{\prime}[\text { proAB lacl } \mathrm{Z} \Delta \mathrm{M} 15 \text { tet }]\end{array}$ & & Stratagene \\
\hline KUR1351 & araD139 $\Delta$ lacU169 rpsL thi $\Delta$ pyrB usp-4 dctA & & Baker et al. (1996) \\
\hline \multicolumn{4}{|l|}{ Plasmids } \\
\hline pRL101 & $\Delta p y r D a a m p$ & E. coli & This work \\
\hline pIP61 & pyrDa $a^{+}$amp & E. coli & Andersen et al. (1994) \\
\hline pED201 & pyrDa ${ }^{+}$amp kan & E. coli & This work \\
\hline pED202 & pyrDa ${ }^{+}$amp kan erm & L. lactis, E. coli & This work \\
\hline $\mathrm{pG}^{+}$Host 4 & erm orits & L. lactis, E. coli & Maguin et al. (1992) \\
\hline pCR2.1-TOPO & amp kan & E. coli & Invitrogen \\
\hline pDBORO & oroP rep ${ }^{+}$ & L. lactis & This work \\
\hline pDBORO-XbaI & oroP rep ${ }^{+}$ & L. lactis & This work \\
\hline pDBORO-EcoRV & oroP rep ${ }^{+}$ & L. lactis & This work \\
\hline pED105 & $\Delta p y r D b$ amp kan & E. coli & This work \\
\hline pED204 & $\Delta p y r D b$ amp kan erm & L. lactis, E. coli & This work \\
\hline pED112 & $(\text { oroP } y s b B A)^{+}$amp kan & E. coli & This work \\
\hline pCI3340 & $\mathrm{cam}$ & L. lactis, E. coli & Hayes et al. (1990) \\
\hline pED210 & $(\text { oroP } y s b B A)^{+}$cam & L. lactis, E. coli & This work \\
\hline pGD268 & neo & E. coli & Antoniewski et al. (1990) \\
\hline pED301 & $(\text { oroP ysbB })^{+}$neo & E. coli & This work \\
\hline pMBK701 & amp kan oroP $P^{+}$ & L. lactis, E. coli & This work \\
\hline
\end{tabular}

${ }^{*} \mathrm{NCDO}$, National Collection of Dairy Organisms, Reading, UK.

$\dagger$ CHCC, Chr. Hansen’s Culture Collection.

Detection of $\alpha$-amylase activity in $B$. subtilis. The $\alpha$-amylase phenotype of B. subtilis clones on LB agar plates containing $1 \%$ starch was analysed by adding a solution of $0.5 \%$ iodine and $1 \%$ potassium iodine to the plates on which the strains had been growing overnight. The $\alpha$-amylase-producing colonies formed a clear halo, whereas the $\alpha$ amylase-negative colonies did not.

Growth experiments and orotate uptake. Starting with fresh colonies from GSA plates with erythromycin, strains were grown for
6-8 h at $30{ }^{\circ} \mathrm{C}$ in $10 \mathrm{ml} \mathrm{GSA}$ medium with erythromycin. Different dilutions of the growing culture were added to $10 \mathrm{ml}$ medium and grown overnight. From an exponentially growing culture, new medium was inoculated to $\mathrm{OD}_{436} 0.05$. The growth experiments were performed in plastic flasks without stirring. For uptake experiments, $500 \mu \mathrm{l}$ cells at $\mathrm{OD}_{436} 0.8$ were transferred to an Eppendorf tube containing $\left[{ }^{14} \mathrm{C}\right]$ orotate at a specific activity of $52 \mathrm{mCi} \mathrm{mmol}^{-1}\left(1924 \mathrm{MBq} \mathrm{mmol}^{-1}\right)$. After 1,3 and $5 \mathrm{~min}$ the medium was removed by filtration through a $0.22 \mu \mathrm{m}$ filter. The filter 
Table 2. Primers used in this work

\begin{tabular}{|ll|}
\hline Name & \\
\hline 268neo & CTCATTCCence \\
\hline pyrDaBamHI & CGGGATCCATGACCGCACCAACAGC \\
pyrDaNcoI & CATGCCATGGCCAAATCCATCTTTAGGC \\
pyrDaHindII & CGTGAAGCTTGACAAAATAGGCTGACCTC \\
pyrDbIF & CGGAAGATCTGATGATGACAGTTGTCAG \\
pyrDbIR & CTGTACTGGTCCATAAGCTCGGATCCACCAAAACAACCTGACGCTG \\
pyrDbIIF & CAGCGTCAGGTTGTTTTGGTGATCCGAGCTTATGGACCAGTACAG \\
pyrDbIIR & TCGGAGATCTATCCAAGGACAAGTGCAG \\
DBORO2 & ACTTATCGTCCGGACTTG \\
DBORO04 & TTCACGCTCACTACCTTC \\
DBORO8 & CATTAGAAAGCGCACGAC \\
DBORO15 & GACCGCCAGTTAGAAGCC \\
DBORO16 & TTGTGATTTTTAGATAGGG \\
DBORO18 & GAATAAGCTGATATTAGCCCC \\
DBORO20 & GGCTCACCATTTTGGCCTCTGG \\
DBORO22BamHI & CAGGATCCTACTGACAGACTTGTCAG \\
DBORO23EcoRI & GAGAATTCTGATTCGGACAAGGCTTC \\
DBORO24EcoRI & GAGAATCAAAGTCGTTCGCCTCAAG \\
DBORO26 & TAAGTCCTGCCTTTTAACCG \\
DBORO27 & TCATTTCCATAGTTGCCACC \\
CS105 & ACGGTCGACACGCTGTTCCATATTACTAG \\
\hline
\end{tabular}

was washed twice with $5 \mathrm{ml}$ water. After drying, the radioactivity on the filters was determined in a scintillation counter.

Phylogenetic analysis. The GenBank program protein-protein BLAST at NCBI (http://www.ncbi.nlm.nih.gov/BLAST) was used to find similar proteins. Phylogenetic analysis was performed by a CLUSTAL $\mathrm{W}$ alignment used in a cluster analysis at the TreeTop Phylogenetic Tree Prediction server (http://www.genebee.msu.su/ services/phtree_reduced.html). The corresponding phylogenetic tree was obtained at the Phylodendron Phylogenetic tree printer (http:// www.es.embnet.org/Doc/phylodendron/treeprint-sample1.html).

\section{RESULTS}

\section{Orotate metabolism by lactococci}

As described above, orotate disappears during cheese production using $L$. lactis starter cultures. In order to investigate orotate metabolism, the model strain L. lactis subsp. lactis MG1363 was analysed for its ability to utilize orotate as measured by its sensitivity to 5 -fluoroorotate, as both compounds are metabolized by the same enzymes of nucleotide metabolism (Fig. 1). Surprisingly, MG1363 was found to be completely resistant. Moreover, the pyrimidine-requiring derivative ED79.1175 was only able to grow in the presence of uracil but not orotate. The uptake of uracil has previously been shown to be facilitated by a dedicated uracil transporter encoded by the chromosomally located pyrP (Martinussen et al., 2001).

To determine whether the inability to utilize orotate is a general trait among L. lactis strains, 11 strains (nos 1-11 in Table 1) were screened for their sensitivity to 5 -fluoroorotate.
Streaking the strains on defined SA medium containing $50 \mu \mathrm{g} 5$-fluoroorotate $\mathrm{ml}^{-1}$ showed that only two strains, DB0410 and 901-1, were affected by 5-fluoroorotate: their growth was inhibited, suggesting that they were able to metabolize orotate in significant amounts. Both strains were further analysed on defined GSA medium with different 5 fluoroorotate concentrations $\left(5,10,20\right.$ and $\left.50 \mu \mathrm{g} \mathrm{ml}^{-1}\right)$. No growth of either strain was observed at a concentration of $20 \mu \mathrm{g} \mathrm{ml}^{-1}$. Growth was severely reduced at $5 \mu \mathrm{g} \mathrm{5-}$ fluoroorotate $\mathrm{ml}^{-1}$ for both strains.

The genes encoding the enzymes for lactose and casein degradation, required for growth in milk, have been found to be plasmid-borne in lactococci. Since orotate is present in high amounts in cow's milk (Motyl et al., 1991), we examined whether the ability of DB0410 and 901-1 to utilize orotate was plasmid dependent. Plasmids were indeed present in DB0410 and 901-1 as judged by agarose gel electrophoresis of crude extracts (not shown). The plasmid preparations were used to transform the pyrimidine-auxotrophic strain L. lactis ED79.1175 (pyrDa pyrDb), a derivative of $L$. lactis MG1363, and streaked on defined GSA medium supplemented with $100 \mu \mathrm{g}$ orotate $\mathrm{ml}^{-1}$ as sole pyrimidine source. MG1363 is unable to metabolize orotate since the strain is resistant to 5-fluoroorotate, and ED79.1175 is unable to utilize orotate as sole pyrimidine source. After 2 days, more than 1000 transformants were obtained with the total plasmid preparation of DB0410, while after 4 days, only 5 transformants were obtained with the plasmid preparation isolated from 901-1. No colonies appeared on GSA plates without orotate, indicating that the transformants obtained had acquired orotate-utilization 
genes. Thirty-six DB0410 transformants and the five 901-1 transformants were restreaked on GSA agar plates supplemented with 100,50 and $20 \mu \mathrm{g}$ orotate $\mathrm{ml}^{-1}$, or with $20 \mu \mathrm{g}$ uracil $\mathrm{ml}^{-1}$. Strain ED79.1175 transformed with plasmid DNA from DB0410 grew equally well on orotate and uracil. In contrast, ED79.1175 transformed with plasmid DNA from strain 901-1 did not grow efficiently on orotate when supplied at $50 \mu \mathrm{g} \mathrm{ml}{ }^{-1}$. It was decided to further characterize the strains originating from the transformation with DB0410 DNA.

The plasmid profile of five transformants was analysed and all of them harboured only a single plasmid. It was named pDBORO, and the size was roughly estimated by restriction fragment analysis to be about $16 \mathrm{kbp}$. The restriction enzyme map is shown in Fig. 2. The complete DNA sequence of the plasmid was determined on both strands with an error rate less then $0.01 \%$ and a redundancy of at least 2.

\section{Genetic organization of pDBORO}

The sequence assembly of pDBORO was confirmed by PCR and by restriction endonuclease analysis (not shown). pDBORO amounts to $16404 \mathrm{bp}$ and has a $\mathrm{G}+\mathrm{C}$ content of $35.16 \mathrm{~mol} \%$ (GENEMARK program) (Lukashin \& Borodovsky, 1998), which is in agreement with the overall $\mathrm{G}+\mathrm{C}$ content $(35.4 \mathrm{~mol} \%)$ of the L. lactis subsp. lactis strain IL1403 genome sequence (Bolotin et al., 2001). Sequence analysis revealed the presence of 19 ORFs, but ORF prediction carried out with the software programs GENEMARK (Lukashin \& Borodovsky, 1998) and EasyGene (Larsen \& Krogh, 2003) suggested only 15 ORFs (Table 3). Coding density is $77.8 \%$, which is lower than the coding density (86\%) of the IL1403 genome (Bolotin et al., 2001). The general organization is shown in Fig. 2(a).

Detailed sequence analysis and comparison with DNA databases showed that the pDBORO plasmid contains

(a)

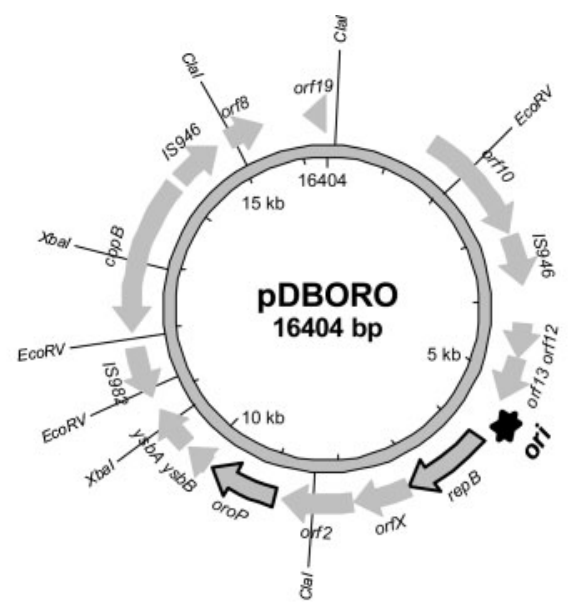

(b)
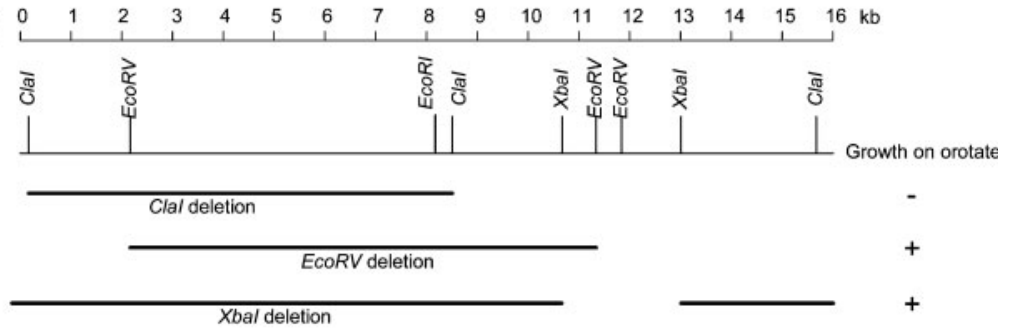
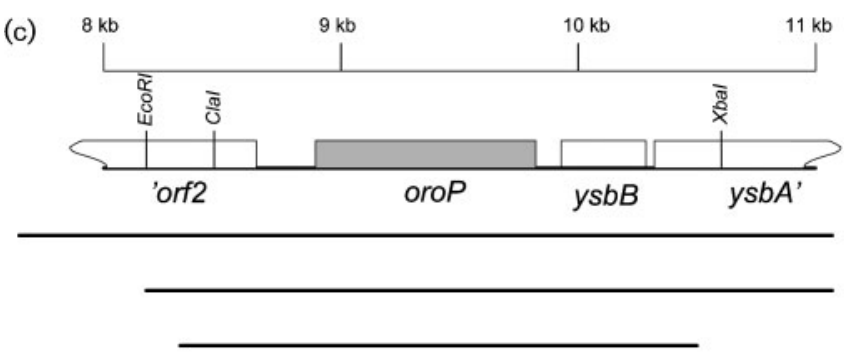

pED112

pED210

pED301

pMKB701
Fig. 2. Map of the orotate plasmid pDBORO isolated from $L$. lactis subsp. lactis biovar diacetylactis. (a) Genetic map of pDBORO. Refer to Table 3 for a description of the individual ORFs. (b) Restriction map and deletion analysis of pDBORO. The black lines represent the DNA sequences present in the plasmids obtained by restriction enzyme digestion followed by ligation using pDBORO DNA. The ability of the deletions to confer growth on orotate as sole pyrimidine source in a pyrimidine-requiring mutant is shown as + . (c) Physical map of the oro $P$ region. The plasmids shown could all confer growth on orotate as sole pyrimidine source in a pyrimidine-requiring mutant. 
Table 3. Predicted ORFs in pDBORO

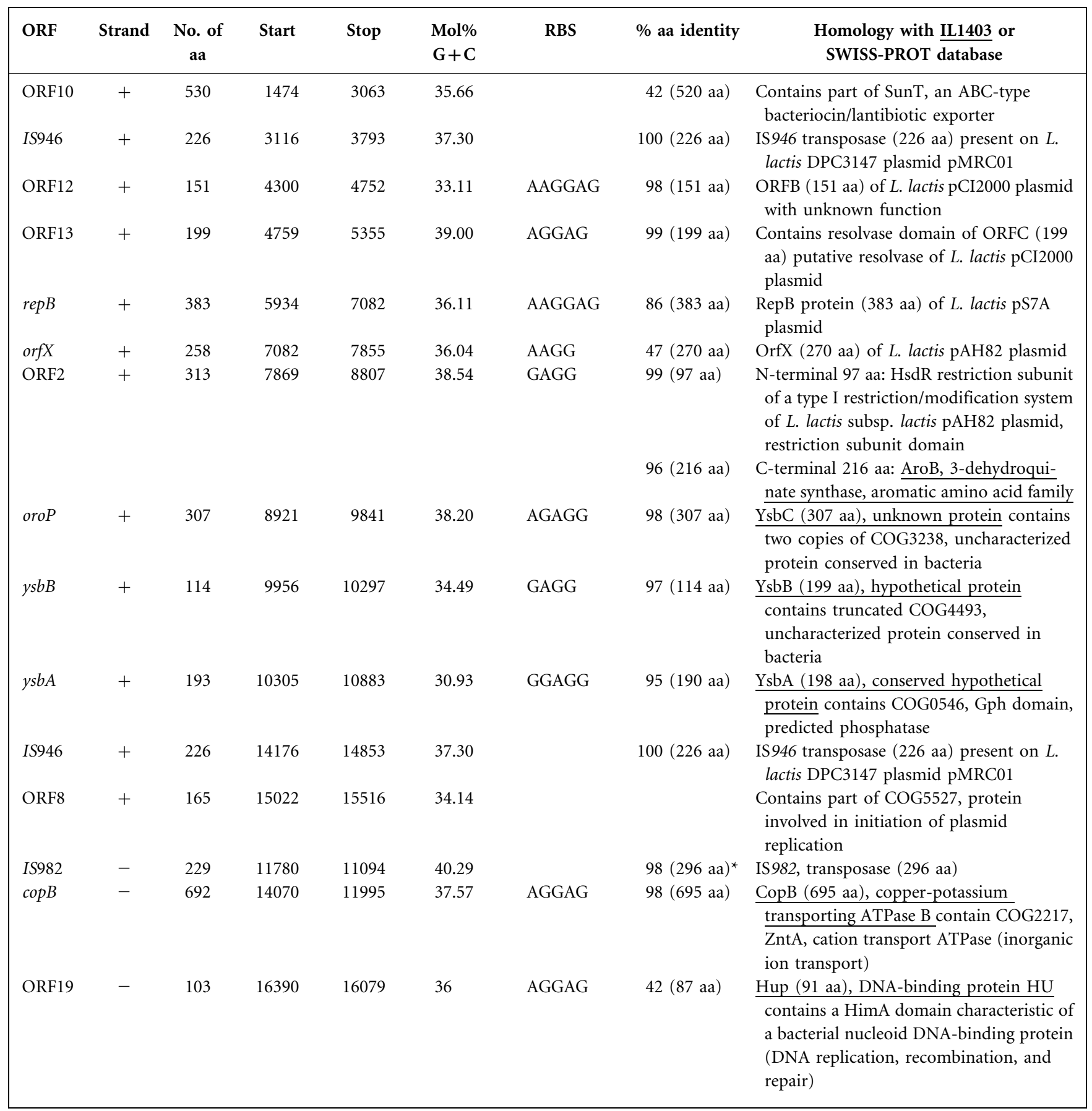

${ }^{\star}$ Th pDBORO IS982 transposase gene contain a C688T mutation resulting in an early stop. The pDBORO IS982 gene product is truncated and consists of only 229 aa residues.

several regions with very high identity either to the IL1403 chromosomal sequence or to other lactococcal plasmids. Regions 8159-10873 and 11975-14104 have $96 \%$ and $97 \%$ identity to the IL1403 sequence and regions 3887-5373 and 7589-8158 have $95 \%$ and $99.1 \%$ identity to pCI2000 (accession no. AF178424, unpublished) and pAH82 (O'Sullivan et al., 2001), respectively. Similarities between plasmid sequences have been described for other lactococcal plasmids such as pAH90, which indicates a high frequency of horizontal transfer among the lactococci and an overall plasticity in plasmid structures (O'Sullivan et al., 2001).

Table 3 lists the properties of the ORFs and their closest relatives based on BLAST searches. Two of the three IS elements are identical and nearly identical (96\%) to IS946, including the $18 \mathrm{bp}$ inverted repeats (Romero \& 
Klaenhammer, 1990). One IS946 is inserted before ORF8 and the second IS946 is inserted in the end of ORF10. The third IS element is nearly identical $(98 \%)$ to IS982 (Yu et al., 1995b) but the 999 bp IS982 on pDBORO is flanked by 16-perfect instead of 18-perfect inverted repeats and has a $\mathrm{C}$ to $\mathrm{T}$ mutation at position 778 . This mutation creates a stop codon in the ORF encoding the transposase, which results in a truncated transposase of 229 instead of 296 aa.

An ORF encoding a protein of 383 aa with high similarity to RepB proteins, an ORF encoding a 258 aa OrfX-like protein and ORF2 are part of the replication module and are described below. The $\operatorname{cop} B$ gene most probably codes for a copper-potassium-transporting ATPase B first identified in Enterococcus hirae (Odermatt et al., 1993) as they are $98 \%$ identical. The deduced amino acid sequence of $\operatorname{copB}$ located in the IL1403 genome contains an HNM repetition in the $\mathrm{N}$-terminal part which is lacking in the deduced amino acid sequence of $\operatorname{cop} B$ in pDBORO. Three ORFs, ORF10, ORF8 and ORF19, encode proteins with low amino acid sequence identity ( $42 \%$ or less) to known proteins but in two ORFs a (partial) functional domain could be identified (Table 3). ORF10 encodes a protein of 530 aa showing homology to SunT of the ABC-type bacteriocin/lantibiotic exporter from B. subtilis (Paik et al., 1998). The 50 C-terminal amino acids are however missing, and the last $22 \mathrm{bp}$ of ORF10 overlap with the downstream IS 946 element and a new stop codon is created by a read-through into the IS 946 sequence. ORF19 encodes a 103 aa protein with a domain found in bacterial nucleoid DNA-binding proteins. The deduced amino acid sequence of ORF8 shows no significant similarity to any protein in the databases searched. The DNA fragment between position 3887 and 5373 contains two ORFs, ORF12 and ORF13, which are nearly identical to ORFB (98\%), with unknown function, and ORFC (98.5\%), a putative resolvase. Both homologues are found on plasmid pCI200.

\section{The replication module of pDBORO}

Between positions 5934-7082 and 7082-7855, a noncoding sequence and ORFs were found that are normally involved in the replication of theta-type plasmids (Frere et al., 1993; Gravesen et al., 1995; Hayes et al., 1991). The rep $B$ gene codes for a protein of 383 aa with a high amino acid sequence identity to initiator replication proteins of other theta-replicating lactococcal plasmids. The highest identity was found with RepB of the pS7A plasmid (86.4\%; accession no. NC_004652), the food-grade cloning vector pVS40 (85.6\%) (von Wright \& Raty, 1993), pCI305 (82\%) (Hayes et al., 1990), pCI605 (82\%; accession no. NC_002138), pAH33 (82\%) (O'Sullivan et al., 2001) and pDR1-1 (82\%; accession no. NC_004163).

Upstream of the repB gene, between positions 5625 and 5933, a region is found that shows high identity at the nucleotide level $(80 \%)$ with the cis-acting ori region and the upstream sequence of the repB gene in the lactococcal plasmid pCD4 (Emond et al., 2001). Moreover, this region shows the same organization of secondary structures, including a $41 \mathrm{bp}$ AT-rich box flanked by a GCC and GCGTGG cluster and followed by a tandem of three and a half perfect direct repeats of $22 \mathrm{bp}$.

\section{The oroP gene found on PDBORO encodes an orotate transporter}

To identify the genes responsible for orotate utilization, pDBORO deletion derivatives were constructed (Fig. 2b). Three deletions were made. The pDBORO DNA was digested with XbaI, EcoRV or $\mathrm{ClaI}$ and diluted prior to ligation to enhance self-ligation. Ligation mixtures were transformed into L. lactis ED79.1175 (pyrDa pyrDb) and plated on GSA agar plates containing $20 \mu \mathrm{g}$ orotate $\mathrm{ml}^{-1}$. Only pDBORO derivatives containing the replication module and the orotate transporter coding genes are able to grow. Very few transformants were obtained from the ClaI deletion, but they all contained both ClaI fragments. As shown above, all the functions required for replication are present on one ClaI fragment(Fig. 2b). Several hundred clones were isolated from the two other deletions. This leads to the conclusion that the DNA between the ClaI site at $8.5 \mathrm{~kb}$ and the $\mathrm{XbaI}$ site at $10.5 \mathrm{~kb}$ (Fig. $2 \mathrm{~b}$ ) is required for growth on orotate as sole pyrimidine source. The sequence of the $C l a \mathrm{I}-\mathrm{XbaI}$ fragment revealed the presence of two complete ORFs, oroP and $y s b B$, and two truncated ORFs, orf2 and $y s b A$ (Fig. 2c). As $y s b A$ is truncated in the $X b a \mathrm{I}$ deletion, and orotate utilization is unaffected, it can be concluded that $y s b A$ is not required for orotate metabolism.

To verify that this region of $\mathrm{pDBORO}$ is indeed responsible for orotate uptake, a PCR fragment containing the oroP and $y s b B$ genes was amplified with primers $\mathrm{DBORO} 2$ and DBORO8 and cloned into the $\mathrm{pCI} 3340$ vector, resulting in construct pED210. By electroporation pED210 was introduced into ED79.1175 and transformants were selected on rich medium containing chloramphenicol. As control the vector pCI3340 was also established in ED79.1175. Transformants were screened on GSA agar plates containing chloramphenicol in the absence and presence of $20 \mu \mathrm{g}$ orotate $\mathrm{ml}^{-1}$ as the sole pyrimidine source. Only transformants that harboured pED210 could grow on orotate. This confirmed the results of the plasmid deletion analysis. The plasmid pED210 carries only the oroP and $y s b B$ genes, showing that the ability to metabolize orotate is linked to oroP and/or $y s b B$.

To investigate whether oroP by itself has the ability to facilitate orotate transport, or the $y s b B$ gene is required, plasmid pMBK701 carrying only the oroP gene and the replication module from $\mathrm{pDBORO}$ was constructed by PCR amplification and subsequent cloning in the E. coli pTOPO vector. Transformation into E. coli was unsuccessful. Therefore, the ligation mixture was used to transform L. lactis ED79.1175 with selection for growth on orotate as sole pyrimidine source. Transformants were readily obtained, and a restriction enzyme and PCR analysis 
revealed that they all harboured a plasmid corresponding to $\mathrm{pMBK} 701$. It was verified that the plasmid contained the oroP gene in addition to the pTOPO vector. This finding indicates that the only gene on $\mathrm{pDBORO}$ conferring the ability to utilize orotate is oroP. The purified plasmid was transformed into $E$. coli by selecting for ampicillin resistance, and an analysis of transformants showed that the plasmids suffered from deletions. As pTOPO is a highcopy-number plasmid, it is reasonable to conclude that overexpression of oroP alone is detrimental to E. coli.

To verify that oroP facilitates orotate transport, an uptake assay using $\left[{ }^{14} \mathrm{C}\right]$ orotate was performed. Fig. $3(\mathrm{a})$ shows a representative experiment in which the L. lactis strains MG1363, DB0410 and MG1363/pED210 (oroP) were assayed for their ability to facilitate orotate uptake. The presence of plasmid pED210 conferred orotate uptake ability to MG1363. Moreover, the uptake was linear right from the start, indicating that orotate is not converted extracellularly.

In order to verify that orotate is directly taken up and not converted prior to transport, growth of a
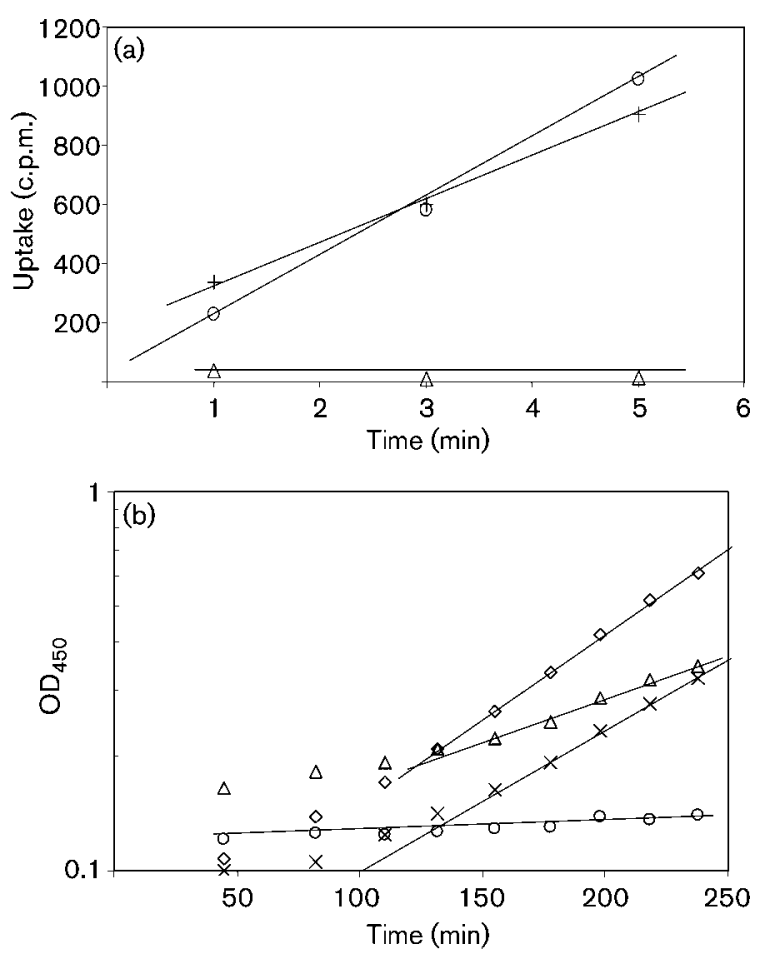

Fig. 3. Orotate uptake. (a) Uptake of $\left[{ }^{14} \mathrm{C}\right]$ orotate by L. lactis MG1363 $(\triangle)$, L. lactis MG1363/pED210 $(\bigcirc)$ and $L$. lactis DB0410 (+). The radioactivity in $500 \mu$ filtered culture was determined in a scintillation counter after 1, 3 and 5 min incubation with $5 \mu \mathrm{M}\left[{ }^{14} \mathrm{C}\right]$ orotate. (b) Growth of $L$. lactis ED79.1175/ pDBORO in GSA medium at $30{ }^{\circ} \mathrm{C}$ with uridine or orotate as sole pyrimidine source in the absence and presence of $10 \mu \mathrm{M}$ azauracil. $\diamond$, Uridine; $\times$, uridine and azauracil; $\triangle$, orotate; $\bigcirc$, orotate and azauracil. pyrimidine-requiring strain in the presence of orotate and 6-azauracil was assayed. 6-Azauracil is converted to 6azaUMP, known as a very potent inhibitor of the orotate monophosphate (OMP) decarboxylase (Miller et al., 2000). During such a condition, it would be expected that orotate would be phosphoribosylated to OMP, but not further decarboxylated to UMP (Fig. 1), and hence unable to support growth. In the experiment shown in Fig. 3(b) strain ED79.1175 (pyrDa pyrdDb) harbouring pDBORO was grown with uridine or orotate as sole pyrimidine source in the presence and absence of 6-azauracil. Only the utilization of orotate, and not that of uridine, was impaired by 6 -azauracil. Since OMP decarboxylase is inhibited by 6-azaUMP, this result strongly suggests that orotate is indeed taken up by the cell and not converted prior to transport. It could be argued that OMP is formed outside the cell and subsequently transported, but this is extremely unlikely, since 5-phospho-D-ribosyl 1-pyrophosphate (PRPP) is required for the reaction, and phosphorylated compounds with a few exotic exceptions are unable to cross the cytoplasmic membrane.

Based on the DNA sequence, OroP was determined to consist of 207 aa. The deduced sequence was analysed using the TMHMM Server (http://www.cbs.dtu.dk/services/ TMHMM), and the overall structure suggests that OroP is a membrane protein with nine transmembrane regions (Fig. 4a). Using the SignalP 3.0 server (http:// www.cbs.dtu.dk/services/SignalP) the signal peptide cleavage site in OroP was predicted to be between Ala23 and Asp24 (Fig. 4b). A BLASTP search showed that OroP belongs to a group of conserved hypothetical membrane proteins. Thus, these observations indicate that oroP encodes an orotate transporter, as found in the uptake experiments.

\section{The oroP, $y s b A$, and $y s b B$ genes are found on the chromosome of $\boldsymbol{L}$. lactis}

The L. lactis strains IL1403 and MG1363 are resistant to 5fluoroorotate, indicating that they are unable to metabolize significant amounts of exogenous orotate. Moreover, introduction of the oroP gene conferred 5-fluoroorotate sensitivity to MG1363. Hence, lack of orotate transport is the reason why MG1363 is unable to metabolize this compound.

As mentioned previously, homology searches using the $y s b A, y s b B$ and $o r o P$ reading frames as queries surprisingly revealed that homologues of these genes are present on the chromosome of L. lactis IL1403. The genes are annotated as $y s b A, y s b B$ and $y s b C$, coding for proteins with unknown functions (Bolotin et al., 2001). The oroP gene was originally annotated as $y s b C$, but is here renamed according to its function. The gene order oroP-ysbB-ysbA is conserved in both the plasmid pDBORO and the IL1403 chromosome. Compared to IL1403, the deduced oroP amino acid sequence has five amino acid substitutions. Four substitutions conserve a hydrophobic side-chain, whereas the fifth changes an arginine to a glutamine residue. An 
(a)

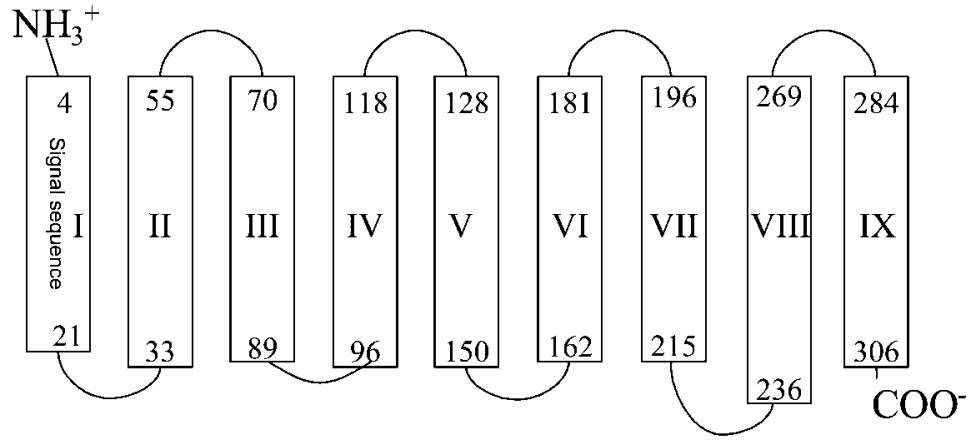

(b)

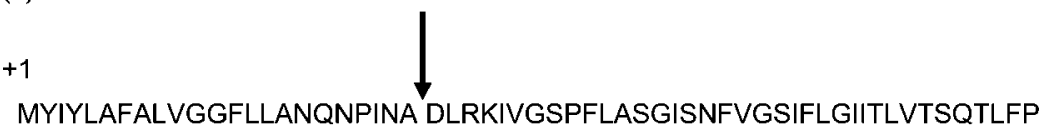

Fig. 4. Analysis of the orotate transporter encoded by oro $P$ present on the orotate plasmid pDBORO isolated from $L$. lactis subsp. lactis biovar diacetylactis. (a) Prediction of the nine transmembrane helices $(I-I X)$ in the deduced amino acid sequence using the TMHMM server (http://www.cbs. dtu.dk/services/TMHMM). The $\alpha$-helices are shown by rectangles and the numbers refer to the amino acid sequence. The first $\alpha$-helix $(I)$ is predicted to be part of the signal sequence. (b) The signal sequence predicted by the SignalP server (http://www.cbs.dtu.dk/services/SignalP). The signal peptide cleavage site in OroP was predicted to be between Ala23 and Asp24.
oroP homologue exhibiting $89 \%$ identity with the oroP ORF was also found in the chromosome of $L$. lactis MG1363 by searching the genome sequence at GenBank (accession no. AM406671). The gene order oroP (llmg_1937 in the MG1363 sequence)-ysbB (llmg_1936) was conserved in MG1363 whereas $y s b A$ seems to be absent. An oroP allele was also found in the chromosome of L. lactis SK11 by a protein-protein BLAST search at NCBI (http://www.ncbi.nlm.nih.gov/BLAST).

\section{oroP homologues are primarily found in Gram-positives}

In order to determine whether putative orotate transporters are widespread, a bioinformatics approach was used to analyse the presence of oroP homologues in the databases. A protein-protein BLAST search using the server at NCBI revealed a number of putative proteins with homology to OroP from pDBORO. Two kinds of protein sequences showed homology to OroP: a long form with similar length to OroP and a short version. Interestingly, the long form seems to have emerged from a duplication of a conserved domain, DUF606, found in ORFs with unknown function. The long version was only found in Gram-positives.

In order to establish their relationship, a cluster analysis based on a CLUSTAL W alignment was conducted. Only the long versions were included. The resulting phylogenetic tree is shown in Fig. 5. OroP homologues from L. lactis are tightly clustered, and in general, the relationships among the different OroP homologues are clustered according to the relationship of the different strains. The OroP homologue from Lactobacillus plantarum is of special interest. The original sequence is most likely wrongly annotated, since it is elongated by 47 aa compared to the OroP homologues from other organisms, and a much better Shine-Dalgarno sequence is present in front of the second methionine codon (data not shown). The oroP homologue from $L b$. plantarum (annotated as lp_2696 in the genome sequence) is located immediately downstream of the pyrE gene of the pyrimidine biosynthetic operon, and since no terminators are found between pyrE and lp_2696 they could be co-transcribed, making the oroP homologue a member of the pyr regulon of $L$. plantarum. This finding, and the membrane protein characteristics of lp_2696, suggests that it is involved in pyrimidine transport.

\section{The orotate transporter system confers 5- fluoroorotate sensitivity to $L$. lactis wild-type strains}

Plasmids pCI3340 and pED210 were transformed into $L$. lactis NCDO712 and its plasmid-cured counterpart MG1363, both resistant to 5-fluoroorotate and prototrophic for pyrimidines. Transformants were selected by the acquired chloramphenicol resistance. Subsequently, the transformants were screened for 5-fluoroorotate sensitivity. No growth of L. lactis NCDO712 or MG1363 harbouring pED210 was seen on 5-fluoroorotate-containing agar plates, indicating that oroP confers sensitivity to 5fluoroorotate in both strains.

\section{The orotate transporter is functional in both $E$. coli and $B$. subtilis}

In order to investigate whether the orotate transport system is functional in other organisms, E. coli and $B$. subtilis strains harbouring the oroP gene from pDBORO were analysed either by the ability of orotate to fulfil a pyrimidine requirement of an auxotrophic mutant or by sensitivity to 5-fluoroorotate of a wild-type strain. Both methods probe for the presence of a functional orotateuptake system.

Plasmid pED301 was transformed into E. coli KUR1351 ( $p y r D$ dctA) and E. coli XL1-Blue. The KUR1351 transformants were plated on selective ABTG medium supplemented 


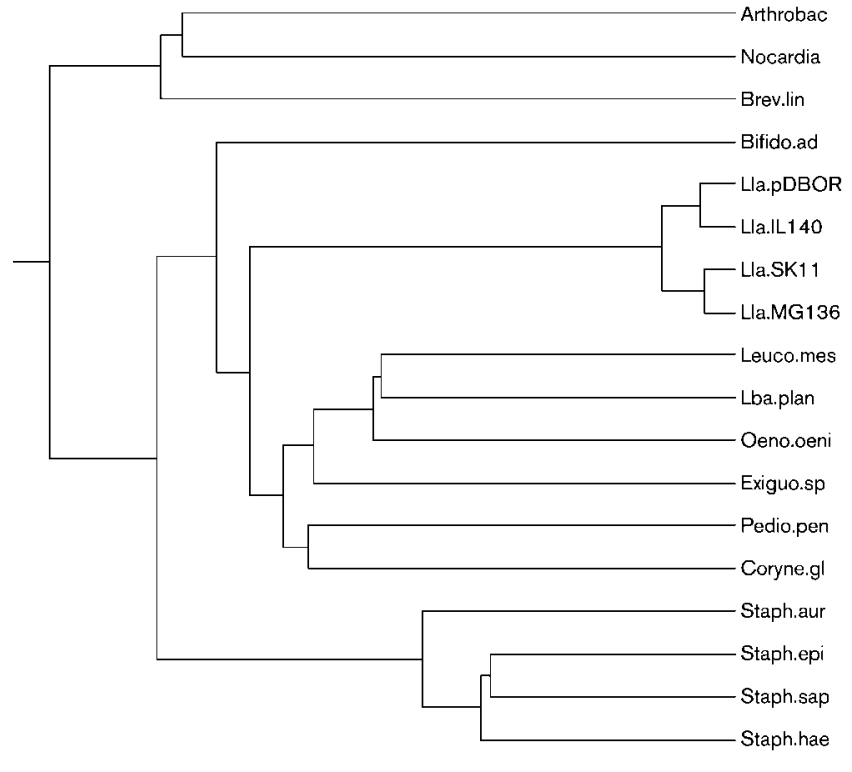

Fig. 5. Phylogenetic tree of OroP homologues obtained from alignment of related protein sequences found by a protein-protein BLAST search. The cluster analysis was performed at http:// www.genebee.msu.su/services/phtree_reduced.html, and the phylogenetic tree was was constructed using Phylodendron Phylogenetic tree printer server at http://www.es.embnet.org/ Doc/phylodendron/treeprint-sample1.html. GenBank accession numbers and strain names are as follows: Arthrobac, ZP_00411831 Arthrobacter sp. FB24; Nocardia, BAD54985 Nocardia farcinica IFM 10152; Brev.lin, ZP_00381369 Brevibacterium linens BL2; Bifido.ad, ZP_01028822 Bifidobacterium adolescentis; Lla.pDBOR, Lactococcus lactis plasmid pDBORO (this work); Lla.IL140, AAK05853 Lactococcus lactis subsp. lactis I1403; Lla.SK11, ZP_00382583 Lactococcus lactis subsp. cremoris SK11; Lla.MG136, BH770678 Lactococcus lactis subsp. cremoris MG1363; Leuco.mes, ZP_00063719 Leuconostoc mesenteroides subsp. mesenteroides ATCC 8293; Lba.plan, CAD64939 Lactobacillus plantarum WCFS1; Oeno.oeni, ZP_00319123 Oenococcus oeni PSU-1; Exiguo.sp, ZP_00537982 Exiguobacterium sp.; Pedio.pen, ZP_00322824 Pediococcus pentosaceus ATCC 25745; Coryne.gl, BAB98464 Corynebacterium glutamicum ATCC 13032; Staph.aur, CAG42360 Staphylococcus aureus subsp. aureus MSSA476; Staph.epi, AAO03989 Staphylococcus epidermidis ATCC 12228; Staph.sap, BAE19246 Staphylococcus saprophyticus subsp. saprophyticus ATCC 15305; Staph.hae, BAE05588 Staphylococcus haemolyticus JCSC1435.

with orotate as sole pyrimidine source, whereas XLI-Blue transformants were screened on 5-fluoroorotate (Table 4). B. subtilis strain ED358 (pyrB oro $P^{+}$) was streaked on selective $\mathrm{MM}$ agar plates containing $5 \mu \mathrm{g}$ neomycin $\mathrm{ml}^{-1}$ without or with $20 \mu \mathrm{g}$ orotate $\mathrm{ml}^{-1}$ or $20 \mu \mathrm{g}$ uracil ml $\mathrm{ml}^{-1}$ as sole pyrimidine source. B. subtilis strain ED348 $\left(\right.$ oroP $\left.^{+}\right)$was streaked on selective $\mathrm{MM}$ agar plates containing $5 \mu \mathrm{g}$ neomycin $\mathrm{ml}^{-1}$ with and without $20 \mu \mathrm{g}$ 5-fluoroorotate $\mathrm{ml}^{-1}$. Results are shown in Table 4 .
The L. lactis orotate transporter is able to mediate 5fluoroorotate sensitivity to both $B$. subtilis 168 and $E$. coli XL1-Blue. Surprisingly, XL1-Blue was resistant to $20 \mu \mathrm{g} 5$ fluoroorotate $\mathrm{ml}^{-1}$. E. coli wild-type is normally sensitive to this drug due to the presence of the $d c t A$ gene product (Baker et al., 1996). Since XL1-Blue is sensitive to 5-fluoroorotate only in the presence of $o r o P$, it is reasonable to believe that this highly manipulated strain has an additional mutation in dctA. Moreover, oroP is required for the ability of the pyrimidine-auxotrophic derivative of B. subtilis, ED358, and of E. coli KUR1351, to grow on orotate as sole pyrimidine source. These results show that OroP is also capable of facilitating the uptake of orotate and 5-fluoroorotate in both E. coli and B. subtilis and, consequently, must be correctly folded and inserted in the plasma membrane.

\section{DISCUSSION}

\section{Orotate uptake is mediated by specific transporters}

Kneifel et al. (1992) and Saidi \& Warthesen (1989) observed that the orotate concentration in milk decreased during fermentation with lactic acid bacteria, including $L$. lactis cultures, suggesting that at least some L. lactis strains are able to metabolize orotate. As orotate and 5fluoroorotate are both metabolized by the same enzymes in the pyrimidine biosynthesis pathway (Fig. 1), sensitivity to 5-fluoroorotate is a powerful method to demonstrate orotate uptake. Among 11 tested strains only two, DB0410 and 901-1, were 5-fluoroorotate sensitive, meaning that these two strains can utilize orotate; this implies that orotate utilization is not a general property of L. lactis. Both strains were sensitive at a low concentration, suggesting the presence of a high-affinity transporter for orotate. The two sensitive strains belong to different subspecies: DB0410 is a strain of L. lactis subsp. lactis biovar diacetylactis, used as a starter culture for production of cheese and cultured buttermilk (Curic et al., 1999), while 901-1 belongs to the cremoris subspecies (Braun et al., 1989). The property to utilize orotate seems therefore to be strain-dependent rather than species-dependent.

Many functions related to growth in milk are found on plasmids in L. lactis, presumably acquired during their adaptation process, as the original niche of lactococci is believed to be plants (Efstathiou \& McKay, 1976; McKay et al., 1976; Yu et al., 1995a, 1996). It was therefore interesting to investigate if the orotate transporter genes were also plasmid-borne. For both L. lactis DB0410 and 901-1, single plasmids were isolated after transferring total plasmid preparations into the pyrimidine-auxotrophic strain ED79.1175 and analysing the transformants for their orotate utilization as sole pyrimidine source, but only pDBORO from L. lactis DB0410 was further characterized.

The oroP gene responsible for orotate uptake in L. lactis was shown to code for a protein of 307 aa with the overall 
Table 4. Growth of $E$. coli and B. subtilis harbouring the orotate transporter from L. lactis

+ , Growth; -, no growth. Agar plates were incubated for 1 day at $37{ }^{\circ} \mathrm{C}$. ND, Not determined.

\begin{tabular}{|c|c|c|c|c|c|c|c|}
\hline \multirow[t]{2}{*}{ Species } & \multirow[t]{2}{*}{ Strain } & \multirow[t]{2}{*}{ Plasmid } & \multirow[t]{2}{*}{ Relevant genotype } & \multicolumn{4}{|c|}{ Supplement* } \\
\hline & & & & None & Uracil $_{20}$ & Orotate $_{20}$ & $5-\mathrm{FO}_{20} \dagger$ \\
\hline E. coli & KUR1351 & pGD268 & & - & + & - & ND \\
\hline E. coli & KUR1351 & pED301 & $(\text { oroP-ysbBA })^{+}$ & - & + & + & $\mathrm{ND}$ \\
\hline E. coli & KUR1351 & pED112 & $(\text { oroP-ysbBA })^{+}$ & - & + & + & ND \\
\hline E. coli & XLI-Blue & pGD268 & & + & $\mathrm{ND}$ & ND & + \\
\hline E. coli & XLI-Blue & pED301 & neo $(\text { oroP-ysbB) })^{+}$ & + & $\mathrm{ND}$ & $\mathrm{ND}$ & - \\
\hline B. subtilis & ED364 & & & + & $\mathrm{ND}$ & $\mathrm{ND}$ & + \\
\hline B. subtilis & ED368 & & $(\text { oroP-ysbB-ysbA) })^{+}$ & + & $\mathrm{ND}$ & $\mathrm{ND}$ & - \\
\hline B. subtilis & ED344 & & pyrB & - & + & - & $\mathrm{ND}$ \\
\hline B. subtilis & ED358 & & pyrB $(\text { oroP-ysbB })^{+}$ & - & + & + & $\mathrm{ND}$ \\
\hline
\end{tabular}

${ }^{\star}$ The supplements to ABT glucose agar plates for E. coli and MM glucose plates for B. subtilis are in $\mu \mathrm{g} \mathrm{ml}^{-1}$.

$\dagger 5$-FO, 5-fluoroorotate.

structure of a membrane protein consisting of nine transmembrane regions. To our knowledge, this is the first time an orotate transporter has been identified and cloned in a Gram-positive bacterium. The $\mathrm{C}_{4}$-dicarboxylate transport protein DctA was identified to mediate orotate uptake in the Gram-negative bacteria E. coli, Salmonella typhimurium and Sinorhizobium meliloti (Baker et al., 1996; Yurgel \& Kahn, 2005). OroP shows no homology to DctA.

\section{An oroP homologue is present in the chromosome of $L$. lactis strains}

Surprisingly, an oroP homologue was found in the sequenced genome of IL1403 but IL1403 is resistant to 5 -fluoroorotate, indicating that this homologue does not confer the ability to utilize orotate in significant amounts.

The question to be answered is why one homologue codes for a transporter protein that is able to mediate orotate uptake and the other does not. Both deduced amino acid sequences have the overall structure of a membrane protein consisting of nine transmembrane regions, and they differ by only five conservative substitutions. This suggests that the changes in the amino acid sequence do not account for the inability of the IL1403 oroP homologue to facilitate significant orotate uptake. More likely, it could be a matter of gene expression; both a higher promoter strength and the fact that oroP is present in multiple copies when encoded on pDBORO may account for its capability to facilitate transport of sufficient 5-fluoroorotate for the cell to become sensitive to the drug. We are currently investigating whether a low expression of the chromosomally located gene is responsible for the inability to mediate orotate transport, and whether an increased expression of the chromosomal allele could confer sufficient orotate uptake capability.

\section{The potential of oroP as a selection/ counterselection marker}

The functionality of oroP in other organisms has been assessed and we showed that the $L$. lactis orotate transporter is able to mediate 5-fluoroorotate sensitivity in B. subtilis 168, E. coli XL1-Blue, and 5-fluoroorotate sensitive lactococci. Moreover, oroP is required for the ability of the pyrimidine-auxotrophic derivative of $B$. subtilis, ED358, E. coli KUR1351 and L. lactis ED1175 to grow on orotate as sole pyrimidine source.

Based on the results obtained, the oroP orotate transporter system has potential as a selection/counterselection marker. For application in food, vectors should contain selection markers that are acceptable in the food industry. In general, selection is mostly carried out with the use of antibiotic markers, and food-grade alternatives are rare (Pedersen et al., 2005). The oroP gene originates from the L. lactis plasmid pDBORO and can be applied as a food-grade selective marker. In order for oroP to function as a selection marker, the host must have a pyrimidine requirement caused by a mutation in a gene encoding an enzyme in the first part of the biosynthetic pathway, since the pathway from orotate to UMP encoded by pyrE and pyrF must be intact for orotate taken up by OroP to be metabolized (Fig. 1). Mutants in the first part of the pyrimidine biosynthetic pathway can be obtained either by genetic engineering or by mutagenesis followed by a penicillin counterselection against growth in the absence of uracil. Both methods have successfully been utilized to obtain uracil auxotrophic mutants in L. lactis (Martinussen et al., 2001).

The presence of oroP in the cell results in sensitivity to 5fluoroorotate. The oroP gene can be exploited as a counterselection marker to select for the loss of a function/plasmid simply by streaking the strains on defined medium containing 5-fluoroorotate. Whereas the use of 
oroP as a selection marker requires a specific genetic background, its utilization as a counterselection marker only requires that the background strain is unable to transport 5-fluoroorotate. Many organisms are unable to utilize orotate, and those strains that do encode an orotate transporter can easily be modified simply by selecting a 5 fluoroorotate-resistant derivative. Whereas different selection markers are abundantly available, counterselection markers are rare. Therefore, the counterselection property of the oroP system is particularly useful, especially when taking into account that the system may be functional in a large number of organisms (Martinussen \& Defoor, 2005).

Previously, an alternative counterselection system has been developed in our lab. It exploits the $u p p$ gene, whose presence results in sensitivity to 5 -fluorouracil (Breuner et al., 1999; Martinussen \& Hammer, 1994, 1995). This system requires that the background strain is mutated in the $u p p$ gene. Since the $u p p$ gene is very abundant, and not always very easy to obtain, the exploitation of oroP as a counterselection marker is more straightforward.

Interestingly, oroP could only be maintained in $E$. coli in the presence of the downstream gene $y s b B$, whereas oroP could be established in L. lactis in the absence of $y s b B$. The reason for the toxic effect of oroP in the E. coli host in the absence of $y s b B$ could be that $y s b B$ encodes either a regulatory protein, or a chaperone involved in assembly and/or translocation of OroP to the membrane. We are currently trying to solve this problem, making the utilization of the gene easier in different organisms.

\section{ACKNOWLEDGEMENTS}

Rasmus Larsen is acknowledged for the construction of pRL101, Kim Sørensen from Chr. Hansen for donating strains from their culture collection, and Karin Hammer for discussions and critical reading of the manuscript. This work was supported by grants from the Danish Agricultural and Veterinary Research Council and the Danish Centre for Advanced Food Studies.

\section{REFERENCES}

Andersen, P. S., Jansen, P. J. \& Hammer, K. (1994). Two different dihydroorotate dehydrogenases in Lactococcus lactis. J Bacteriol 176, 3975-3982.

Andersen, P. S., Martinussen, J. \& Hammer, K. (1996). Sequence analysis and identification of the pyrKDbF operon from Lactococcus lactis including a novel gene, pyrK, involved in pyrimidine biosynthesis. J Bacteriol 178, 5005-5012.

Antoniewski, C., Savelli, B. \& Stragier, P. (1990). The spoIIJ gene, which regulates early developmental steps in Bacillus subtilis, belongs to a class of environmentally responsive genes. J Bacteriol 172, 86-93.

Baker, K. E., Ditullio, K. P., Neuhard, J. \& Kelln, R. A. (1996). Utilization of orotate as a pyrimidine source by Salmonella typhimurium and Escherichia coli requires the dicarboxylate transport protein encoded by dctA. J Bacteriol 178, 7099-7105.

Biswas, I., Gruss, A., Ehrlich, S. D. \& Maguin, E. (1993). Highefficiency gene inactivation and replacement system for gram-positive bacteria. J Bacteriol 175, 3628-3635.
Bolotin, A., Wincker, P., Mauger, S., Jaillon, O., Malarme, K., Weissenbach, J., Ehrlich, S. D. \& Sorokin, A. (2001). The complete genome sequence of the lactic acid bacterium Lactococcus lactis ssp. lactis IL1403. Genome Res 11, 731-753.

Boylan, R. J., Mendelson, N. H., Brooks, D. \& Young, F. E. (1972). Regulation of the bacterial cell wall: analysis of a mutant of Bacillus subtilis defective in biosynthesis of teichoic acid. J Bacteriol 110, 281-290.

Braun, V., Jr, Hertwig, S., Neve, H., Geis, A. \& Teuber, M. (1989). Taxonomic differentiation of bacteriophages of Lactococcus lactis by electron microscopy, DNA-DNA hybridization, and protein profiles. $J$ Gen Microbiol 135, 2551-2560.

Breuner, A., Brondsted, L. \& Hammer, K. (1999). Novel organization of genes involved in prophage excision identified in the temperate lactococcal bacteriophage TP901-1. J Bacteriol 181, 7291-7297.

Chopin, A., Chopin, M. C., Moillo-Batt, A. \& Langella, P. (1984). Two plasmid-determined restriction and modification systems in Streptococcus lactis. Plasmid 11, 260-263.

Clark, D. J. \& Maaloe, O. (1967). DNA replication and the cell cycle in Escherichia coli. J Mol Biol 23, 99-112.

Curic, M., Stuer-Lauridsen, B., Renault, P. \& Nilsson, D. (1999). A general method for selection of alpha-acetolactate decarboxylasedeficient Lactococcus lactis mutants to improve diacetyl formation. Appl Environ Microbiol 65, 1202-1206.

Efstathiou, J. D. \& McKay, L. L. (1976). Plasmids in Streptococcus lactis: evidence that lactose metabolism and proteinase activity are plasmid linked. Appl Environ Microbiol 32, 38-44.

Emond, E., Lavallee, R., Drolet, G., Moineau, S. \& LaPointe, G. (2001). Molecular characterization of a theta replication plasmid and its use for development of a two-component food-grade cloning system for Lactococcus lactis. Appl Environ Microbiol 67, 1700-1709.

Frere, J., Novel, M. \& Novel, G. (1993). Molecular analysis of the Lactococcus lactis subspecies lactis CNRZ270 bidirectional theta replicating lactose plasmid pUCL22. Mol Microbiol 10, 1113-1124.

Gasson, M. J. (1983). Plasmid complements of Streptococcus lactis NCDO 712 and other lactic streptococci after protoplast-induced curing. J Bacteriol 154, 1-9.

Gravesen, A., Josephsen, J., von Wright, A. \& Vogensen, F. K. (1995). Characterization of the replicon from the lactococcal theta-replicating plasmid pJW563. Plasmid 34, 105-118.

Hayes, F., Daly, C. \& Fitzgerald, G. F. (1990). Identification of the minimal replicon of Lactococcus lactis subsp. lactis UC317 plasmid pCI305. Appl Environ Microbiol 56, 202-209.

Hayes, F., Vos, P., Fitzgerald, G. F., de Vos, W. M. \& Daly, C. (1991). Molecular organization of the minimal replicon of novel, narrowhost-range, lactococcal plasmid pCI305. Plasmid 25, 16-26.

Holo, H. \& Nes, I. F. (1995). Transformation of Lactococcus by electroporation. Methods Mol Biol 47, 195-199.

Huggins, A. R. \& Sandine, W. E. (1977). Incidence and properties of temperate bacteriophages induced from lactic streptococci. Appl Environ Microbiol 33, 184-191.

Jensen, P. R. \& Hammer, K. (1993). Minimal requirements for exponential growth of Lactococcus lactis. Appl Environ Microbiol 59, 4363-4366.

Johansen, E. \& Kibenich, A. (1992). Characterization of Leuconostoc isolates from commercial mixed strain mesophilic starter cultures. J Dairy Sci 75, 1186-1191.

Jorgensen, C. M., Hammer, K. \& Martinussen, J. (2003). CTP limitation increases expression of CTP synthase in Lactococcus lactis. J Bacteriol 185, 6562-6574. 
Jorgensen, C. M., Hammer, K., Jensen, P. R. \& Martinussen, J. (2004). Expression of the pyrG gene determines the pool sizes of CTP and dCTP in Lactococcus lactis. Eur J Biochem 271, 2438-2445.

Kilstrup, M. \& Martinussen, J. (1998). A transcriptional activator, homologous to the Bacillus subtilis PurR repressor, is required for expression of purine biosynthetic genes in Lactococcus lactis. J Bacteriol 180, 3907-3916.

Kilstrup, M., Hammer, K., Ruhdal, J. P. \& Martinussen, J. (2005). Nucleotide metabolism and its control in lactic acid bacteria. FEMS Microbiol Rev 29, 555-590.

Kneifel, W., Kaufmann, M., Fleischer, A. \& Ulberth, F. (1992). Screening of commercially available mesophilic dairy starter cultures: biochemical, sensory, and microbiological properties. J Dairy Sci 75, 3158-3166.

Larsen, T. S. \& Krogh, A. (2003). EasyGene - a prokaryotic gene finder that ranks ORFs by statistical significance. BMC Bioinformatics 4, 21 .

Lukashin, A. V. \& Borodovsky, M. (1998). GeneMark.hmm: new solutions for gene finding. Nucleic Acids Res 26, 1107-1115.

Maguin, E., Duwat, P., Hege, T., Ehrlich, D. \& Gruss, A. (1992). New thermosensitive plasmid for gram-positive bacteria. J Bacteriol 174, 5633-5638.

Mandel, M. \& Higa, A. (1992). Calcium-dependent bacteriophage DNA infection. 1970. Biotechnology 24, 198-201.

Marcinkeviciene, J., Tinney, L. M., Wang, K. H., Rogers, M. J. \& Copeland, R. A. (1999). Dihydroorotate dehydrogenase B of Enterococcus faecalis. Characterization and insights into chemical mechanism. Biochemistry 38, 13129-13137.

Marcinkeviciene, J., Jiang, W., Locke, G., Kopcho, L. M., Rogers, M. J. \& Copeland, R. A. (2000). A second dihydroorotate dehydrogenase (Type A) of the human pathogen Enterococcus faecalis: expression, purification, and steady-state kinetic mechanism. Arch Biochem Biophys 377, 178-186.

Martinussen, J. \& Defoor, E. M. C. (2005). Novel recombinant marker gene encoding orotate transporter polypeptide, useful as selection maker, screening marker, counter-selection marker or bi-directional marker for identifying and/or selecting cells. Patent no. WO2005078106-A1.

Martinussen, J. \& Hammer, K. (1994). Cloning and characterization of upp, a gene encoding uracil phosphoribosyltransferase from Lactococcus lactis. J Bacteriol 176, 6457-6463.

Martinussen, J. \& Hammer, K. (1995). Powerful methods to establish chromosomal markers in Lactococcus lactis - an analysis of pyrimidine salvage pathway mutants obtained by positive selections. Microbiology 141, 1883-1890.

Martinussen, J. \& Hammer, K. (1998). The $c a r B$ gene encoding the large subunit of carbamoylphosphate synthetase from Lactococcus lactis is transcribed monocistronically. J Bacteriol 180, 4380-4386.

Martinussen, J., Andersen, P. S. \& Hammer, K. (1994). Nucleotide metabolism in Lactococcus lactis: salvage pathways of exogenous pyrimidines. J Bacteriol 176, 1514-1516.

Martinussen, J., Glaser, P., Andersen, P. S. \& Saxild, H. H. (1995). Two genes encoding uracil phosphoribosyltransferase are present in Bacillus subtilis. J Bacteriol 177, 271-274.

Martinussen, J., Schallert, J., Andersen, B. \& Hammer, K. (2001). The pyrimidine operon pyrRPB-carA from Lactococcus lactis. J Bacteriol 183, 2785-2794.

Martinussen, J., Wadskov-Hansen, S. L. \& Hammer, K. (2003). Two nucleoside uptake systems in Lactococcus lactis: competition between purine nucleosides and cytidine allows for modulation of intracellular nucleotide pools. J Bacteriol 185, 1503-1508.
McKay, L. L., Baldwin, K. A. \& Efstathiou, J. D. (1976). Transductional evidence for plasmid linkage of lactose metabolism in Streptococcus lactis C2. Appl Environ Microbiol 32, 45-52.

Miller, B. G., Snider, M. J., Short, S. A. \& Wolfenden, R. (2000). Contribution of enzyme-phosphoribosyl contacts to catalysis by orotidine 5' -phosphate decarboxylase. Biochemistry 39, 8113-8118.

Motyl, T., Krzeminski, J., Podgurniak, M., Witeszczak, C. \& Zochowski, P. (1991). Variability of orotic acid concentration in cow's milk. Endocr Regul 25, 79-82.

O’Sullivan, D., Ross, R. P., Twomey, D. P., Fitzgerald, G. F., Hill, C. \& Coffey, A. (2001). Naturally occurring lactococcal plasmid pAH90 links bacteriophage resistance and mobility functions to a food-grade selectable marker. Appl Environ Microbiol 67, 929-937.

Odermatt, A., Suter, H., Krapf, R. \& Solioz, M. (1993). Primary structure of two P-type ATPases involved in copper homeostasis in Enterococcus hirae. J Biol Chem 268, 12775-12779.

Paik, S. H., Chakicherla, A. \& Hansen, J. N. (1998). Identification and characterization of the structural and transporter genes for, and the chemical and biological properties of, sublancin 168, a novel lantibiotic produced by Bacillus subtilis 168. J Biol Chem 273, 23134-23142.

Pedersen, M. B., Iversen, S. L., Sorensen, K. I. \& Johansen, E. (2005). The long and winding road from the research laboratory to industrial applications of lactic acid bacteria. FEMS Microbiol Rev 29, 611-624.

Potvin, B. W., Kelleher, R. J., Jr \& Gooder, H. (1975). Pyrimidine biosynthetic pathway of Bacillus subtilis. J Bacteriol 123, 604-615.

Romero, D. A. \& Klaenhammer, T. R. (1990). Characterization of insertion sequence IS946, an Iso-ISS1 element, isolated from the conjugative lactococcal plasmid pTR2030. J Bacteriol 172, 4151-4160.

Saidi, B. \& Warthesen, J. J. (1989). Analysis and stability of orotic acid in milk. J Dairy Sci 72, 2900-2905.

Sambrook, J., Fritsch, E. F. \& Maniatis, T. (1989). Molecular Cloning: a Laboratory Manual. Cold Sping Harbor, NY: Cold Spring Habor Laboratory.

Saxild, H. H. \& Nygaard, P. (1987). Genetic and physiological characterization of Bacillus subtilis mutants resistant to purine analogs. J Bacteriol 169, 2977-2983.

Seegers, J. F., Bron, S., Franke, C. M., Venema, G. \& Kiewiet, R. (1994). The majority of lactococcal plasmids carry a highly related replicon. Microbiology 140, 1291-1300.

Suzuki, I., Kato, S., Kitada, T., Yano, N. \& Morichi, T. (1986). Growth of Lactobacillus bulgaricus in milk. 2. Characteristics of purine nucleotides, pyrimidine nucleotides, and nucleic acid synthesis. J Dairy Sci 69, 971-978.

Terzaghi, B. E. \& Sandine, W. E. (1975). Improved medium for lactic streptococci and their bacteriophages. Appl Microbiol 29, 807-813.

von Wright, A. \& Raty, K. (1993). The nucleotide sequence for the replication region of pVS40, a lactococcal food grade cloning vector. Lett Appl Microbiol 17, 25-28.

Wadskov-Hansen, S. L., Martinussen, J. \& Hammer, K. (2000). The pyrH gene of Lactococcus lactis subsp. cremoris encoding UMP kinase is transcribed as part of an operon including the frrl gene encoding ribosomal recycling factor. Gene 241, 157-166.

Wadskov-Hansen, S. L., Willemoes, M., Martinussen, J., Hammer, K., Neuhard, J. \& Larsen, S. (2001). Cloning and verification of the Lactococcus lactis pyrG gene and characterization of the gene product, CTP synthase. J Biol Chem 276, 38002-38009.

Yu, W., Gillies, K., Kondo, J. K., Broadbent, J. R. \& McKay, L. L. (1995a). Plasmid-mediated oligopeptide transport system in lactococci. Dev Biol Stand 85, 509-521. 
Yu, W., Mierau, I., Mars, A., Johnson, E., Dunny, G. \& McKay, L. L. (1995b). Novel insertion sequence-like element IS982 in lactococci. Plasmid 33, 218-225.

Yu, W., Gillies, K., Kondo, J. K., Broadbent, J. R. \& McKay, L. L. (1996).

Loss of plasmid-mediated oligopeptide transport system in lactococci: another reason for slow milk coagulation. Plasmid 35, 145-155.
Yurgel, S. N. \& Kahn, M. L. (2005). Sinorhizobium meliloti dctA mutants with partial ability to transport dicarboxylic acids. J Bacteriol 187, 1161-1172.

Edited by: D. A. Mills 